Journal of Education and Vocational Research

Vol. 4, No. 11, pp. 331-338, Nov 2013 (ISSN 2221-2590)

\title{
Assessing the Needs of People with Disabilities in the Emirate of Abu Dhabi, UAE
}

\author{
Eman Gaad \\ British University in Dubai, Dubai, United Arab Emirates \\ eman.gaad@buid.ac.ae
}

\begin{abstract}
While there are many opportunities for people with disabilities (PWD) in Abu Dhabi (AD), UAE, there hardly been a study of what is required to get such people to meet their full potentials. This study commenced December 2012 and lasted for 4 months. The needs assessment based study tried to answer questions like what is needed to achieve the enhancement of the quality of life of PWD in AD region during and after school/centre times. It also looked at what type of needs (financial, assistive, emotional, and other) those people might have, and what are the needs of the parents of PWD that support the development of their children to reach their full potentials. Adding to that what could be recommended to bridge the gap in such needs. The purpose was mainly to develop a good understanding of the landscape. Benchmarking was undertaken from all private centers and scanning the needs of all parents of PWD in government centers across $\mathrm{AD}$ as well. It is hoped that researching the findings would help to develop the services on offer for PWD in the Emirate of AD. In order to achieve the aims of this study, 8 centres were selected out of the total of 17 which is the number of private centres in AD. The selection was based on size, location and type of disability as a purposeful sample to insure fair representation of the centres. The researcher conducted 8 filed visits of centers in Abu Dhabi and Al Ain to assess their current services, operating model etc. Individual briefs were prepared for every center with comparisons across specific factors. Scanning all the needs of all the parents of people with disability in the government centres across Abu Dhabi was looked at differently. To insure validity of the data and because the Emirati people with disability clustered mainly in government centres, all nine government centres under Zayed Higher Organization for Humanitarian Care were visited and sample interviews (qualitative and quantitative) from all centres were undertaken. Selected participants were used to interview and investigate up close (purposeful sampling). Findings showed that there is a desperate need for support after school hours despite the care offered during school hours for those who are in school age. Parents need support on several levels especially with how to spend quality time with their children with disabilities.
\end{abstract}

Keywords: Disabilities, Abu Dhabi, Education system,

\section{Introduction}

In the United Arab Emirates (UAE) society, the expectation of a student at any school as well as one of the national goals of the UAE education system is to master the curriculum objectives, academic skills (reading, writing, arithmetic) and pass the Mid and End of year Examinations. Consequently, that student will be then upgraded into the higher class for the following year. This is in line with Gaad (2006) who pointed out that 'to achieve the curriculum planning produced and accredited by the Ministry of Education is amongst the vision goals of the UAE'. Parents face many challenges in a society that opened the door for inclusive education by issuing relevant legislations and laws to support the inclusion of people with disability, but yet to raise awareness about eradication of social stigma that related to them and their families. As for the parents of children with disabilities, the principal explained that a major change of attitude had taken place over the last three years (Alborno, 2012). The purpose of this study was mainly to develop a good understanding of the landscape. Benchmarking was undertaken from all private centers and scanning the needs of all parents of PWD in government centers across the Emirate of Abu Dhabi as the large Emirate that contain largest portion of Emirati community in the UAE. It is hoped that researching the findings would help to develop the services on offer for PWD in the Emirate of AD.

Research Questions: What is needed to achieve the enhancement of the quality of life of PWD in AD region during and after school/centre times in terms of financial, assistive, emotional, and other needs? 
- What are the needs of the parents of PWD that support the development of their children to reach their full potentials?

- What could be recommended to bridge the gap in such needs and support the achievement of better life for PWD in AD?

\section{Methodology}

A mixture of quantitative and qualitative data collection methods was applied to raise validity. Benchmarking all Private Centers took place over the period of the field study with 17 private Centers in AD scanning for all needs of all parents of PWD in government centers across the Emirate. In addition, 8 government centers under Zayed Higher Organization for Humanitarian Care. Because the data that needs to be collected involved interviewing parents as well as looking at the numbers when it comes to services, so choice of methodology for this research was based on mixture of qualitative methods which are by nature more descriptive of finer details in the reality of everyday occurrences than Quantitative data would be (Robson, 2002), and quantitative to serve the counting part of the investigation (Cohen0et al., 2000; Creswell, 2009).

\section{Results}

Scanning all the needs of all the parents of people with disability in the government centers across Abu Dhabi was looked at differently. To insure validity of the data and because the Emirati people with disability clustered mainly in government centers, all nine government centers under Zayed Higher Organization for Humanitarian Care were visited and sample interviews (qualitative and quantitative) from all centers were undertaken. Selected participants were used to interview and investigate up close (purposeful sampling).

Service Provider Comparison: The followings are the comparison of 8 sampled private centers across AD. Names were removed and were substituted with numbers for anonymity

\begin{tabular}{|c|c|c|c|c|}
\hline Category & Centre 1 & Centre 2 & Centre 3 & Centre 4 \\
\hline Legal & Private & Private & Private & Private \\
\hline Status & $\begin{array}{l}\text { Registered The Ministry } \\
\text { of Social Affairs }\end{array}$ & $\begin{array}{l}\text { Registered The Ministry } \\
\text { of Social Affairs }\end{array}$ & $\begin{array}{l}\text { Registered The } \\
\text { Ministry of Social } \\
\text { Affairs }\end{array}$ & $\begin{array}{l}\text { Registered The Ministry } \\
\text { of Social Affairs }\end{array}$ \\
\hline Capacity & Total : 177 & Total : 80 & Total 9 as day care & Up to 60 \\
\hline & Enrollment: 77 & Enrollment: 65 & Emirati 5 & More than $50 \%$ Emiratis \\
\hline Age Group & $\begin{array}{l}\text { Emirati: } 12 \\
3.5-20 \text { years }\end{array}$ & $\begin{array}{l}\text { Emirati: } 5 \\
3.0-20 \text { (or }-22 \text { ) years }\end{array}$ & $\begin{array}{l}+ \text { session based } \\
\text { services after school }\end{array}$ & 3 years to 20 years \\
\hline Employees & $\begin{array}{l}\text { Support staff: } 10 \text { (Nurse, } \\
\text { helpers \& driver) } \\
\text { Professional: } 15 \text { ( Head } \\
\text { teacher, deputy. } 1 \text { SLT, } 1 \\
\text { PT, } 1 \text { OT , } 1 \text { Household } \\
\text { SPED: } 8\end{array}$ & $\begin{array}{l}\text { Support staff: } 10 \text { (Nurse, } \\
\text { helpers \& driver) } \\
\text { Professional: } 15 \text { ( Head } \\
\text { teacher, deputy. } 1 \text { SLT, } 1 \\
\text { PT, } 1 \text { OT , } 1 \text { Household } \\
\text { SPED: } 8\end{array}$ & $\begin{array}{l}3 \text { preeminent }+ \text { pay } \\
\text { as you go therapists } \\
\text { for sessions }\end{array}$ & $\begin{array}{l}\text { Employees total } 30 \text { it is } \\
\text { mainly one- to- one } \\
\text { (teacher-student). } \\
\text { Administrators \& special } \\
\text { care. } \\
\text { No more information } \\
\text { found about employees } \\
\text { salary }\end{array}$ \\
\hline
\end{tabular}




\begin{tabular}{|c|c|c|c|c|}
\hline Category & Centre 1 & Centre 2 & Centre 3 & Centre 4 \\
\hline $\begin{array}{l}\text { Physical } \\
\text { Structure }\end{array}$ & $\begin{array}{l}\text { Rented villa } \\
\text { Sport hall } \\
\text { Female household } \\
\text { and needle } \\
\text { workshop } \\
\text { Male carpentry } \\
\text { Computer facilities' } \\
3 \text { classes ( } 12+\text { ) } \\
2 \text { classes ( } 12-\text { ) } \\
1 \text { PMLD class }\end{array}$ & $\begin{array}{l}\text { Computer Facilities all some } \\
\text { classes have one computer } \\
\text { Wide place for a computer lap } \\
\text { A very nice sensory room } \\
\text { donated by Donated by Daman } \\
\text { Standard classroom } \\
\text { Sport facilities are available } \\
\text { They used outside facility for } \\
\text { swimming, horseback riding, } \\
\text { and trips. Playground is in } \\
\text { use for sport }\end{array}$ & $\begin{array}{l}\text { Rented villa } \\
\text { Small and very tight } \\
\text { place } \\
\text { Only } 3 \text { classes }\end{array}$ & $\begin{array}{l}\text { Rented Villa (500.000) } \\
\text { per year. } \\
\text { Big villa divided to } 2 \\
\text { sections (Centre + } \\
\text { Teachers residential). } \\
\text { The Centre itself is } \\
\text { limited and small. } \\
\text { Sport hall. } \\
\text { Household and needle } \\
\text { workshop (girls) } \\
\text { Carpentry for boys } \\
\text { available. }\end{array}$ \\
\hline $\begin{array}{l}\text { Disability } \\
\text { Type }\end{array}$ & $\begin{array}{l}\text { PMLD } \\
\text { Down Syndrome } \\
\text { Intellectual } \\
\text { disability } \\
\text { Speech and } \\
\text { language } \\
\text { impairments }\end{array}$ & $\begin{array}{l}\text { no PMLD } \\
\text { Down Syndrome - almost half } \\
\text { with DS } \\
\text { Intellectual Disability mild to } \\
\text { moderate } \\
\text { Speech and Language } \\
\text { Impairments } \\
\text { Autism - some server and } \\
\text { some mild } \\
\text { No physical problems (Cerepal } \\
\text { Palsy) }\end{array}$ & $\begin{array}{l}\text { Intellectual disability } \\
\text { (Mild/moderate) } \\
\text { Speech and language } \\
\text { impairments } \\
\text { Autism }\end{array}$ & Autism only \\
\hline $\begin{array}{l}\text { Service } \\
\text { Offering }\end{array}$ & $\begin{array}{l}\text { Rehabilitation } \\
\text { Educational } \\
\text { Physiotherapy } \\
\text { Speech \& language } \\
\text { Therapy } \\
\text { Occupational } \\
\text { therapy }\end{array}$ & $\begin{array}{l}\text { Rehabilitation only pre } \\
\text { vocational training, one } \\
\text { student works now in life line } \\
\text { hospital } \\
\text { Educational (inclusion is on } \\
\text { offer but no shadow teacher) } \\
\text { Physiotherapy to all enrolled } \\
\text { Speech and Language Therapy } \\
\text { to all children young and older } \\
\text { Occupational Therapy + Art } \\
\text { Therapy }\end{array}$ & $\begin{array}{l}\text { Rehabilitation } \\
\text { Educational ( special } \\
\text { educator / speech } \\
\text { therapy) } \\
\text { Psychotherapy } \\
\text { Community services }\end{array}$ & $\begin{array}{l}\text { Early Intervention } \\
\text { Inclusion } \\
\text { Speech therapy } \\
\text { Adaptive physical } \\
\text { education } \\
\text { Outdoor activities } \\
\text { Full day services } \\
\text { Art\& vocational } \\
\text { rehabilitation } \\
\text { Neuro feedback } \\
\text { therapy } \\
\text { Family counseling\& } \\
\text { support } \\
\text { Computer services }\end{array}$ \\
\hline Category & Centre 1 & Centre 2 & Centre 3 & Centre 4 \\
\hline Fee & $\begin{array}{l}24,00 \text { Aed per } \\
\text { anum } \\
\text { Red Crescent } \\
\text { pays } 50 \% \text { for } \\
40 \% \text { of enrolled } \\
\text { children } \\
10 \text { out of } 12 \\
\text { Emirati children } \\
\text { are the } \\
\text { beneficiaries }\end{array}$ & $\begin{array}{l}\text { Fees for all children all ages } \\
\text { any type of disability } 8300 \text { per } \\
\text { year so centre is popular but } \\
\text { operation cost is not covered } \\
\text { we have not raised fees for } 6 \\
\text { years }\end{array}$ & $\begin{array}{l}200 \text { Dirham for each } \\
\text { session. } \\
\text { Supposed to be a } \\
\text { private center but it is } \\
\text { "kind of charity as } \\
\text { well". } \\
\text { Red crescent pays for } \\
\text { one family. } \\
\text { Rent increase every } \\
\text { month, which cause a } \\
\text { negative impact on the } \\
\text { financial budget of the } \\
\text { center. }\end{array}$ & $\begin{array}{l}\text { Annual fees for } \\
\text { Centre } 44.000 \\
100 \text { dirham for } \\
\text { each session } \\
\text { No information } \\
\text { found about } \\
\text { employees salary } \\
\text { Red Crescent pays } \\
10.000 \text { for each } \\
\text { student. } \\
\text { Maintenance cost } \\
\text { pays by Centre not } \\
\text { the villa owner }\end{array}$ \\
\hline
\end{tabular}




\begin{tabular}{|c|c|c|c|c|}
\hline $\begin{array}{l}\text { Challenges \& } \\
\text { needs } \\
\text { requirements }\end{array}$ & $\begin{array}{l}\text { Financing the } \\
\text { current cohort } \\
\text { Solving the new } \\
\text { building and } \\
\text { quote issue (8 } \\
\text { millions needs to } \\
\text { be found from } \\
\text { somewhere) } \\
\text { Staff salaries } \\
\text { (average salary } \\
1200 \text { can reach } \\
2000 \text { per month } \\
\text { depending on } \\
\text { experience) } \\
\text { Staff retention } \\
\text { (turn over is high } \\
\text { and that affects } \\
\text { current services } \\
\text { and provision) } \\
\text { Capacity is } 150 \\
\text { and } 77 \text { enrolled }\end{array}$ & $\begin{array}{l}\text { Financing the current staff and } \\
\text { operational cost } \\
\text { Money is needed now to run } \\
\text { the center as salaries are now } \\
\text { taken from } 1 \text { M donated by } \\
\text { one member of the board to } \\
\text { build the new building } \\
\text { Need } 2 \text { M to reach support the } \\
\text { center for next year to develop } \\
\text { It is very difficult to collect } \\
\text { money } \\
\text { Staff salaries (average salary } \\
\text { 2000+500 can reach } 6000 \text { per } \\
\text { month depending } \\
\text { experience) } \\
\text { Staff retention is a problem } \\
\text { some staff leave as they get } \\
\text { head hunted by more paying } \\
\text { centers } \\
\text { Capacity is } 80 \text { and } 65 \text { enrolled } \\
\text { Certain disabilities are not } \\
\text { enrolled as per laws (Visual } \\
\text { and Hearing Impairments) } \\
\text { No shadow teacher for } \\
\text { inclusion access } \\
\text { Surviving...anytime the whole } \\
\text { center could go on stand still } \\
\text { due to lack of fund. 'I am } \\
\text { hunted by the idea of closing } \\
\text { down the center when I am } \\
\text { under pressure to raise } \\
\text { salaries'. }\end{array}$ & $\begin{array}{l}\text { Cohort financing } \\
\text { Gap of } 8 \text { million for } \\
\text { construction funding } \\
\text { Staff salaries average } \\
1,200-2,000 \\
\text { Staff retention is high } \\
\text { Under enrollment ( } 15 \\
\text { per class capacity but } \\
\text { due to staff shortage) } \\
\text { No inclusion access } \\
\text { only these from ZHO as } \\
\text { ADEC has an MOU with } \\
\text { ZHO } \\
\text { Certain disabilities are } \\
\text { not enrolled as per laws } \\
\text { ( visual and hearing) }\end{array}$ & $\begin{array}{l}\text { Need for new big } \\
\text { building. } \\
\text { Need to build } \\
\text { medical Centre. } \\
\text { Need for } \\
\text { occupational } \\
\text { therapy. }\end{array}$ \\
\hline
\end{tabular}

\begin{tabular}{|c|c|c|c|c|}
\hline Category & Centre 1 & Centre 2 & Centre 3 & Centre 4 \\
\hline $\begin{array}{l}\text { Family } \\
\text { needs from } \\
\text { centre } \\
\text { perspective }\end{array}$ & $\begin{array}{l}\text { Financial support for } \\
\text { families who cannot } \\
\text { afford the services } \\
\text { Support after school } \\
\text { time to occupy PWD } \\
\text { time fruitfully } \\
\text { Training on how to } \\
\text { support their children } \\
\text { and carry on what is } \\
\text { the centre doing in } \\
\text { terms of development }\end{array}$ & $\begin{array}{l}\text { Financial support for } \\
\text { families who cannot } \\
\text { afford the services } \\
\text { Support after school } \\
\text { time to occupy PWD } \\
\text { time fruitfully } \\
\text { Training on how to } \\
\text { support their children } \\
\text { and carry on what is } \\
\text { the centre doing in } \\
\text { terms of development }\end{array}$ & $\begin{array}{l}\text { Learn more to } \\
\text { cooperate with the } \\
\text { centre to develop } \\
\text { the child } \\
\text { Counseling for } \\
\text { parents } \\
\text { Training on how to } \\
\text { support their } \\
\text { children and carry } \\
\text { on what is the centre } \\
\text { doing in terms of } \\
\text { development }\end{array}$ & $\begin{array}{l}\text { Expensive devises and } \\
\text { assistive technologies for } \\
\text { their children } \\
\text { Training on how to } \\
\text { support their children and } \\
\text { carry learn how to deal } \\
\text { with Autism } \\
\text { Awareness sessions on } \\
\text { 'denial' as many families } \\
\text { are way too late to enroll } \\
\text { their children in early } \\
\text { intervention and children } \\
\text { lose out }\end{array}$ \\
\hline
\end{tabular}

\begin{tabular}{|c|c|c|c|c|c|c|}
\hline Category & Centre 5 & Centre 6 & & Centre 7 & Centre 8 & \\
\hline Legal Status & $\begin{array}{l}\text { Private } \\
\text { Registered The } \\
\text { Ministry of Social } \\
\text { Affairs }\end{array}$ & $\begin{array}{l}\text { Private } \\
\text { Registered } \\
\text { Ministry of } \\
\text { Affairs }\end{array}$ & $\begin{array}{r}\text { The } \\
\text { Social }\end{array}$ & $\begin{array}{l}\text { Private } \\
\text { Registered The Ministry of } \\
\text { Social Affairs }\end{array}$ & $\begin{array}{l}\text { Government } \\
\text { Registered } \\
\text { Ministry of } \\
\text { Affairs }\end{array}$ & $\begin{array}{l}\text { The } \\
\text { Social }\end{array}$ \\
\hline
\end{tabular}




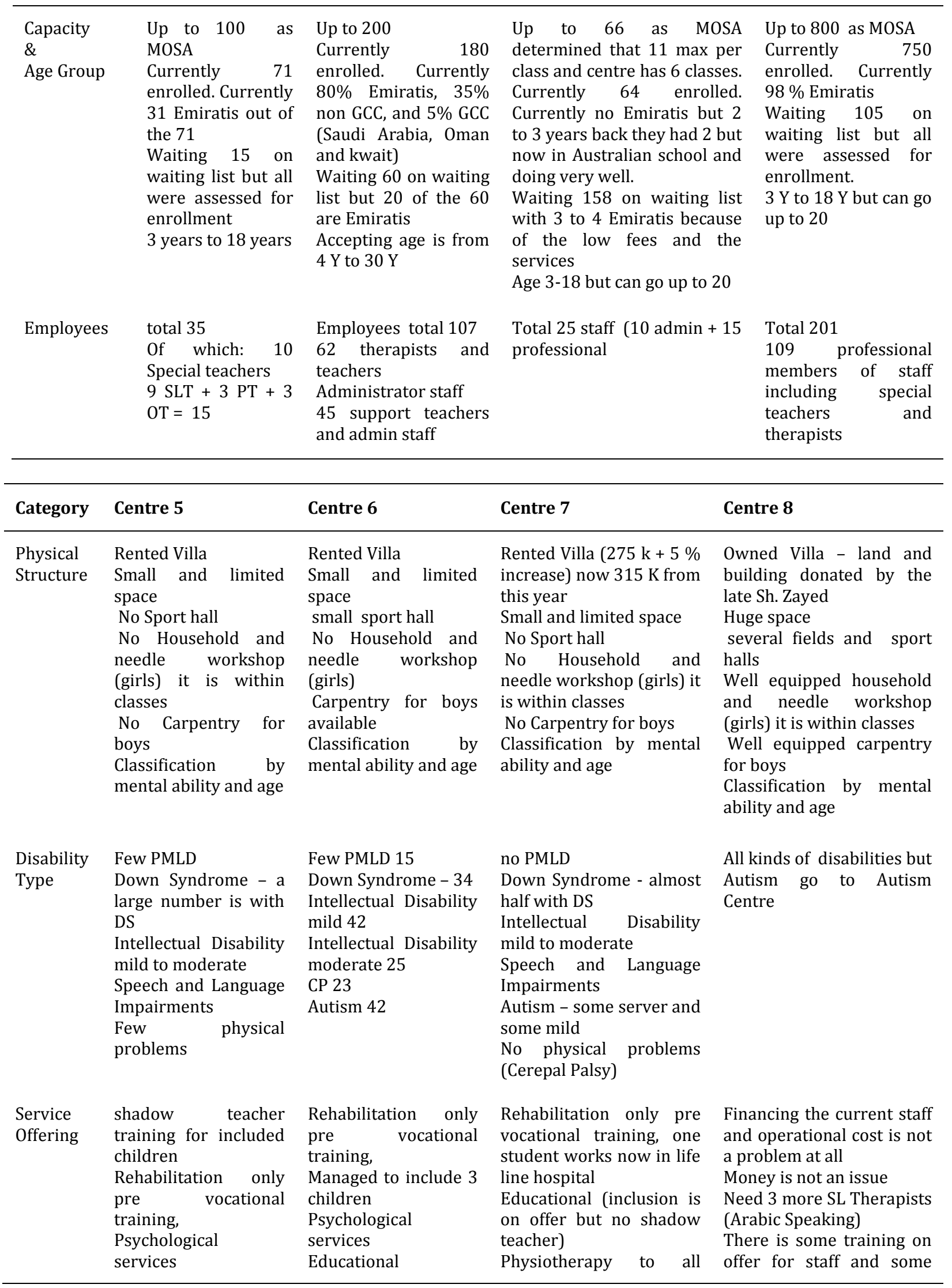




\begin{tabular}{|c|c|c|c|c|}
\hline & $\begin{array}{l}\text { Educational } \\
\text { (inclusion is on offer } \\
\text { but no shadow } \\
\text { teacher) } \\
\text { Physiotherapy to all } \\
\text { enrolled } \\
\text { Audio services } \\
\text { Speech and Language } \\
\text { Therapy to all } \\
\text { children young and } \\
\text { older } \\
\text { Occupational Therapy }\end{array}$ & $\begin{array}{l}\text { (inclusion is on offer } \\
\text { but no shadow } \\
\text { teacher) } \\
\text { Physiotherapy to all } \\
\text { enrolled } \\
\text { Speech and Language } \\
\text { Therapy to all } \\
\text { children young and } \\
\text { older } \\
\text { Occupational Therapy }\end{array}$ & $\begin{array}{l}\text { enrolled } \\
\text { Speech and Language } \\
\text { Therapy to all children } \\
\text { young and older } \\
\text { Occupational Therapy + } \\
\text { Art Therapy }\end{array}$ & $\begin{array}{l}\text { staff travel abroad to } \\
\text { obtain professional } \\
\text { training } \\
\text { Large number of PWD } \\
\text { clustered } \\
\text { Always on the look for best } \\
\text { practices and international } \\
\text { accreditation }\end{array}$ \\
\hline Category & Centre 5 & Centre 6 & Centre 7 & Centre 8 \\
\hline $\begin{array}{l}\text { Family needs } \\
\text { from centre } \\
\text { perspective }\end{array}$ & $\begin{array}{l}\text { Financial Support } \\
\text { Advice on what to } \\
\text { do and activities } \\
\text { after school time } \\
\text { to occupy PWD } \\
\text { time fruitfully } \\
\text { Advice and } \\
\text { training on how to } \\
\text { be more involved } \\
\text { with their } \\
\text { children }\end{array}$ & $\begin{array}{l}\text { Encourage } \\
\text { families to visit } \\
\text { their sleeping - in } \\
\text { children } \\
\text { Support after } \\
\text { school time to } \\
\text { occupy PWD time } \\
\text { fruitfully } \\
\text { Financial support } \\
\text { Some families } \\
\text { need IT and } \\
\text { assistive } \\
\text { technologies } \\
\text { Example some } \\
\text { physical assistive } \\
\text { devices }\end{array}$ & $\begin{array}{l}\text { Financial Support }- \text { in } \\
\text { desperate needs } \\
\text { Advice on a whole load of } \\
\text { parental support issues like } \\
\text { how to encourage } \\
\text { independence as whatever the } \\
\text { centre is doing it is not } \\
\text { matched at home. } \\
\text { Advice and training on how to } \\
\text { be more involved with their } \\
\text { children } \\
\text { Drive their own children to } \\
\text { school!! } \\
\text { Attend parent events and } \\
\text { evenings and know about the } \\
\text { development of their children }\end{array}$ & $\begin{array}{l}\text { Support after school time } \\
\text { to occupy PWD time } \\
\text { fruitfully } \\
\text { Training on how to } \\
\text { support their children } \\
\text { and carry on what is the } \\
\text { centre doing in terms of } \\
\text { development } \\
\text { Some families need to } \\
\text { adhere to training } \\
\text { already offered by the } \\
\text { centre in order to } \\
\text { support their child } \\
\text { Some families need very } \\
\text { sophisticated one or } \\
\text { more assistive technology } \\
\text { equipment to support the } \\
\text { child such as: } \\
\text { Electronic chair life } \\
\text { Better ventilation } \\
\text { systems }\end{array}$ \\
\hline
\end{tabular}

Summary of Quantitative Date Findings: Here is the list of questions that were circulated for validation and 4 participants suggested some changes as one of the questions was rather misleading and the questionnaire was amended accordingly.

Q1: People with special needs are all with disabilities

Q2: A person with disability is able to make decisions related to his life

Q3: people with intellectual disabilities are with mental disorders

Q4: people with intellectual disabilities have low IQ

Q5: it is better to exclude people with intellectual disabilities from society

Q6: all people with intellectual disabilities need care all the time

Q7: I know best terminology related to referring to people with intellectual disabilities

Q8: all mental disorders are disabilities

Q9: all people with intellectual disabilities have communication disorders

Q10: I have enough knowledge about my child's disability to enable me to deal with him and his peers with similar disability

Q11: I feel confident to deal with any person with intellectual disability

Q12: I can differentiate between intellectual disability and metal disorders such as paranoia

Q13: I can differentiate between communication disorders and metal disorders

Q14: all people with Cerebral Palsy have intellectual disability

Q15: Autism is an intellectual disability 


\begin{tabular}{lllllll}
\hline QN & Yes\% & No\% & \multicolumn{3}{c}{ I Don't know\% } \\
\hline Q1 & Pre & Post & Pre & Post & Pre & Post \\
\hline Q2 & $66 \%$ & $65 \%$ & $21 \%$ & $32 \%$ & $13 \%$ & $3 \%$ \\
Q3 & $38 \%$ & $51 \%$ & $49 \%$ & $38 \%$ & $13 \%$ & $12 \%$ \\
Q4 & $35 \%$ & $41 \%$ & $47 \%$ & $51 \%$ & $18 \%$ & $8 \%$ \\
Q5 & $82 \%$ & $90 \%$ & $11 \%$ & $8 \%$ & $8 \%$ & $2 \%$ \\
Q6 & $7 \%$ & $5 \%$ & $86 \%$ & $95 \%$ & $8 \%$ & $0 \%$ \\
Q7 & $2 \%$ & $4 \%$ & $86 \%$ & $93 \%$ & $13 \%$ & $3 \%$ \\
Q8 & $63 \%$ & $66 \%$ & $13 \%$ & $24 \%$ & $24 \%$ & $10 \%$ \\
Q9 & $13 \%$ & $12 \%$ & $66 \%$ & $78 \%$ & $20 \%$ & $11 \%$ \\
Q10 & $14 \%$ & $23 \%$ & $75 \%$ & $72 \%$ & $11 \%$ & $5 \%$ \\
Q11 & $65 \%$ & $69 \%$ & $11 \%$ & $14 \%$ & $25 \%$ & $17 \%$ \\
Q12 & $65 \%$ & $69 \%$ & $10 \%$ & $14 \%$ & $25 \%$ & $17 \%$ \\
Q13 & $61 \%$ & $78 \%$ & $12 \%$ & $14 \%$ & $22 \%$ & $8 \%$ \\
Q15 & $6 \%$ & $41 \%$ & $33 \%$ & $51 \%$ & $12 \%$ & $8 \%$ \\
\hline
\end{tabular}

Example of analysis of one of the qualitative questions:

Q2: A person with disability is able to make decisions related to his life

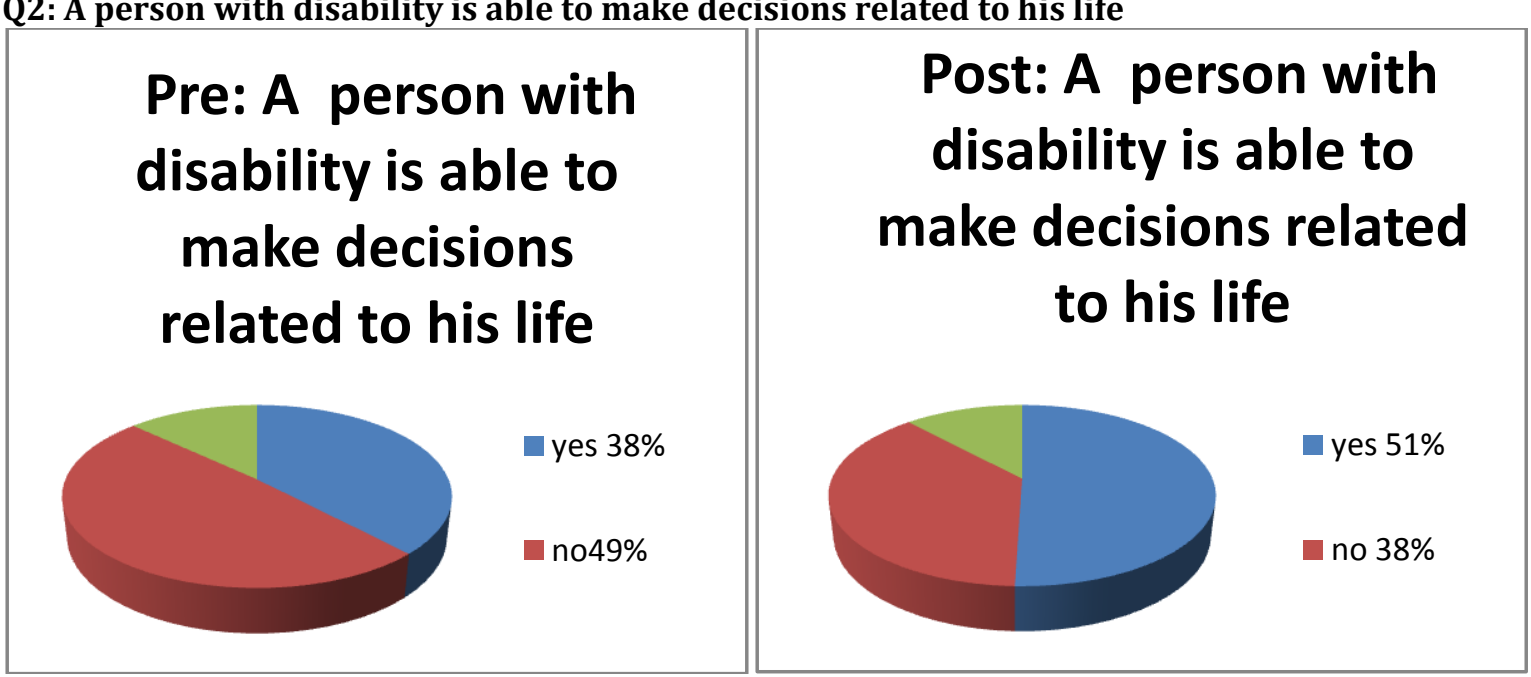




\section{Conclusion and Discussion}

Analysis of data showed that there is a desperate need for support after school hours despite the care offered during school hours for those who are in school age. Parents need support on several levels especially with how to spend quality time with their children with disabilities, something that can be helpful in building the self efficacy to such category of children (Alkire, 2005). In terms of research question 1 which sought whether there was a need for a change or creating new services or provisions, the answer is clearly yes desperate need for support after school hours. In terms of what kind of support parents of children with disability need, there were several levels of support required as per data collected. Training teachers and those who are working with included children with disabilities would was an issue that was raised by parents as an immediate need. This is in line with other studies (Gaad, 2001; Gaad, 2004). While on the long bases, parents wished for Technical support in terms of assistive technologies especially for those with profound multiple disabilities. They have expressed concerns about financial demands on the average family when looking after a child or an adult with disability. Social awareness to support the educational (inclusive) needs of their children were also raised as well as support the therapeutic needs of their children after school hours as some require additional therapy at home that can be more than 20 hours per week. The issues of awareness is reflected in the UAE Constitution of UAE rights for all those who live on the Emirati soil, and was also in the country's vision UAE 2021. And finally despite current law enforcement and legislation to support people with disabilities parents yet felt more Legislative enforcement of their rights are needed across the Emirate of Abu Dhabi.

\section{References}

Alborno, N \& Gaad, E. (2012). Evaluation of the Implementation of a Policy for Adults with Intellectual Disabilities in Dubai: A case study. Journal of Policy and Practice in Intellectual Disabilities, 9(2), 103111

Alkire, S. (2005). Subjective quantitative studies for human agency. Social Indicators Research, 74, 217-260

Cohen, L., Manion, L. \& Morrison, K. (2000). Research methods in Education. $5^{\text {th }}$ ed. London: Routledge Falmer.

Creswell, J. (2009). Research Design, Qualitative, Quantitative, and Mixed Methods Approaches. $3^{\text {rd }}$ ed. Thousand Oaks, CA: Sage.

Gaad, E. (2001) Educating children with Down's syndrome in the United Arab Emirates. British Journal of Special Education, 28(4), 195- 203

Gaad, E. (2004) Cross- cultural perspectives on the effect of cultural attitudes towards inclusion for children with intellectual disabilities. International Journal of Inclusive Education, 8(3), 311- 329

Gaad, E. (2006). The Social and Educational Impacts of the First National Down Syndrome Support Group in the UAE. Journal for Research in Special Educational Needs, 3, 134-142

Robson, C. (2002). Real World Research (2 ${ }^{\text {nd }}$ Ed). Oxford: Blackwell Publishing.

UAE Cabinet. (2010). Constitution of UAE [online]. [Accessed 27 June 2013]. Available at: http://www.uaecabinet.ae/English/UAEGovernment/Pages/ConstitutionOfUAE.aspx

Vision 2021. (2010). United Arab Emirates 2021 Vision [online]. [Accessed 27 December 2012]. Available at:http://www.vision2021.ae/home-page.html 